
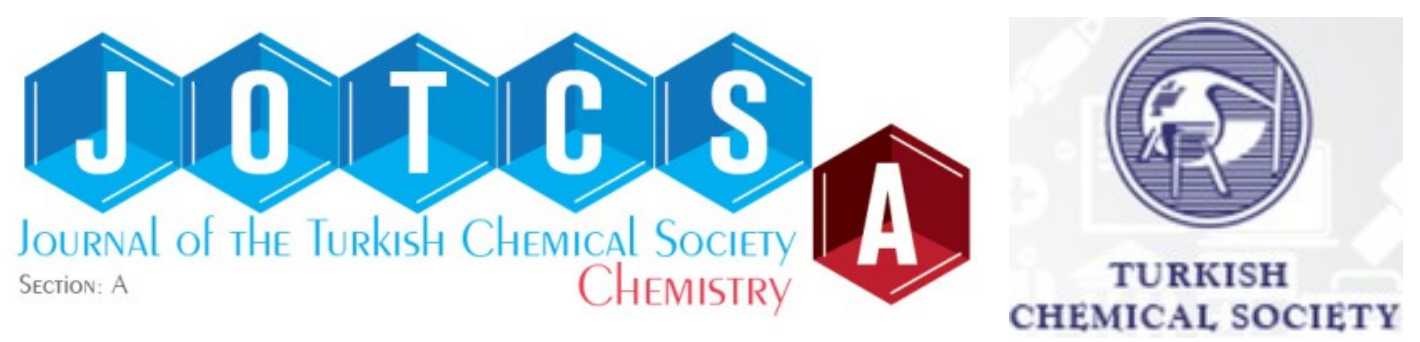

\title{
Novel Mixed Ligand Complexes of Alkaline Earth Metals with Coumarilic Acid and Nicotinamide
}

\author{
Emrah Karaer $\triangle$ ID , Dursun Ali Köse* $\triangle$ (D) \\ Department of Chemistry, Faculty of Arts and Sciences, Hitit University, 19030, Çorum, TURKEY
}

\begin{abstract}
Coordination compounds with mixed ligands were synthesized with $2 \mathrm{~A}$ group $\left(\mathrm{Mg}^{2+}, \mathrm{Ca}^{2+}\right.$, $\mathrm{Ba}^{2+}, \mathrm{Sr}^{2+}$ ) alkaline earth metal cations of coumarilic acid and nicotinamide ligands. Afterward, the structural properties of these new molecules were investigated by melting point, elemental analysis, infrared spectroscopy, thermal analysis (TGA / DTA) curves, powder X-ray diffraction (P-XRD) spectroscopy. It has been suggested that the complex structure with the $\mathrm{Mg}^{2+}$ metal center is different from the other three structures. In this structure, it was determined that four aqua and two nicotinamide ligands were located in the coordination sphere, and the coordination number was six, as expected. With two monoanionic coumarilic acids located outside the coordination sphere, complex charge equivalence was achieved. The other three molecules, $\mathrm{Sr}^{2+}$ and $\mathrm{Ba}^{2+}$, have iso-structural properties, and it is suggested that both structures contain a dinuclear metal center, and two aqua ligands are located in the bridging position between metal centers. Besides, the two coumarilate ligands involved in coordination are thought to coordinate with the primary metal cation through carbonyl and acidic oxygens while coordinating with the secondary metal cation through furan oxygen, providing the third bridge connection between metal centers. Metal cations with nine coordination numbers complete the coordination sphere with two terminal aqua and one nicotinamide ligands, each included in the structure. In the molecule with $\mathrm{Ca}^{2+}$ cation, which differs little from these metal cation structures, the difference according to these structures can be interpreted as the coordination of furan oxygen with the secondary metal center due to the octet coordination of the $\mathrm{Ca}^{2+}$ cation. From the thermal analysis curves, it was determined that only the $\mathrm{Mg}^{2+}$ cation complex contained hydrate. As a result of thermal decomposition, it was determined that relevant metal oxide residues remained in all structures, and this situation was defined by powder XRD.
\end{abstract}

Keywords: Coumarilic acid, alkaline earth metals, coumarin-2-carboxylic acid, spectroscopy, thermal analysis.

Submitted: April 10, 2021. Accepted: May 10, 2021.

Cite this: Karaer E, Köse DA. Novel Mixed Ligand Complexes of Alkaline Earth Metals with Coumarilic Acid and Nicotinamide. JOTCSA. 2021;8(2):659-76.

DOI: https://doi.org/10.18596/jotcsa.912967.

*Corresponding author. E-mail: dalikose@hitit.edu.tr Tel.:+90(364)2277000-1635.

\section{INTRODUCTION}

Furan, benzofuran, and thiophene are aromatic heterocyclic molecules that have been widely studied by chemists and biologists (1). A wide range of biological activity such as benzofuran derivatives, anticancer, antimicrobial, antiinflammatory, antiviral, anti-oxidant, cytotoxic, pesticidal, HIV and enzyme inhibitory (2-6), cardiovascular and antibacterial properties $(7,8)$ is presented. Coumarilic acid with benzofuran ring group (coumarin-2-carboxylic acid, benzo[b]furan carboxylic acid, HCCA) is one example of many derivatives of the coumarin molecule. It is a functional ligand that shows binding properties to monoanionic monodentate or monoanionic 
bidentate through its carboxylate group. It has pharmacophore properties over the benzo[b]furan ring in the structure and can be easily isolated from natural sources (9). Benzo[b]furan functional ring and derivatives are found in different herbal natural food sources such as fruits, herbs, and vegetables (10). It is also one of the main component molecules of drugs (such as amiodarone and bergapten) that have been synthesized recently and were used in many applications $(11,12)$. It is well known that many heterocyclic compounds containing oxygen atoms in the ring chain exhibit important biological properties such as antiarrhythmic, spasmolytic, antiviral, anticancer, antifungal, and antiinflammatory activities (13-19). In particular, benzofuran carboxylic derivatives are applied in different fields such as biological, electronic, pharmaceutical, and agricultural chemicals $(20,21)$.

Although the coordination compounds in which coumarilic acid uses metal cations as central atoms exist in the literature (22-27), the number of studies on structural characterizations is limited $(25,26,28)$. Whether the coumarilate ligand binds as a monodentate bridge or terminal ligand or participates in coordination as a bidentate chelating ligand depends on the reaction conditions and the type of metal cation (22-24, 28-31). The synthesis of these complexes has gained importance due to the therapeutic properties of the element copper against common diseases of our time such as cancer, Parkinson's, Alzheimer's, diabetes, and cardiovascular diseases (32-35). By using the electrochemical synthesis method, pure ligand complexes of coumarilic acid with $\mathrm{Cu}$ (II) and $\mathrm{Zn}$ (II) metal cations were synthesized and structurally investigated. In addition, mixed ligand complex structures of $\mathrm{Co}$ (II), $\mathrm{Ni}(\mathrm{II}), \mathrm{Cu}(\mathrm{II})$, and $\mathrm{Zn}$ (II) metal cations secondary to nicotinamide, $\mathrm{N}, \mathrm{N}$-diethylnicotinamide, and 1,10-phenanthroline were synthesized, and their structural properties were investigated. (36-41).

Coordination compounds of alkali and alkaline earth metal cations are preferred over transition or lanthanide metal cations due to their cheap, watersoluble, and non-toxic properties (42). Magnesium, one of the alkaline earth metals, is known to play an important role in various biological systems due to its binding to proteins, complexing with anions, and free availability (43). Magnesium deficiency may be an essential factor in the pathogenesis of ischemic heart disease, cardiomyopathy, and some arrhythmias (43-47). Coordination compounds containing alkaline earth metal cations have begun to see considerable favor, especially in bioinorganic chemistry (48). The coordination behavior of $\mathrm{Mg}^{2+}$ and $\mathrm{Ca}^{2+}$ metal cations has attracted the attention

of many studies because of the important role of these ions in biological processes (49-51). Coordination occurs mainly through ion-dipole and ion-induced dipole interactions that contribute to binding. However, covalent interaction is possible through the transfer of electron density from bound ligand orbitals to empty or p-orbitals $(52,53)$.<smiles>O=C(O)c1cc2ccccc2o1</smiles>

(a)

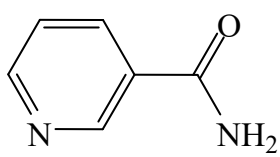

(b)

Figure 1: Molecular formulas of ligands (a) coumarilic acid, (b) nicotinamide.

In the report presented, coordination compounds containing $2 \mathrm{~A}$ group metal cations $\mathrm{Mgg}^{2+}, \mathrm{Ca}^{2+}$ $\mathrm{Sr}^{2+}$, and $\mathrm{Ba}^{2+}$ ] coumarilic acid (Figure 1a) and nicotinamide (Figure 1b) ligands of the periodic table were synthesized. The structural properties of the molecules obtained were characterized using powder X-ray diffraction (P-XRD), UV-Vis spectroscopy, and infrared analysis methods. TG/DTG/DTA curves were recorded to determine the thermal behavior of molecules.

\section{EXPERIMENTAL}

\section{Material and synthesis}

$\left(\mathrm{CH}_{3} \mathrm{COO}\right)_{2} \mathrm{Mg} .4 \mathrm{H}_{2} \mathrm{O}$

(magnesium (calcium

(strontium

acetate), acetate), $\left(\mathrm{CH}_{3} \mathrm{COO}\right)_{2} \mathrm{Sr} \cdot 1 / 2 \mathrm{H}_{2} \mathrm{O}$ $\mathrm{Ba}\left(\mathrm{CH}_{3} \mathrm{COO}\right)_{2}$ (barium acetate), coumarilic acid, and nicotinamide used in the synthesis of the complexes were obtained from Sigma-Aldrich.

0.001 moles of magnesium acetate, calcium acetate, strontium acetate, and barium acetate were taken and dissolved in 30 milliliters of distilled water and transferred to flat-bottomed flasks. The solutions of $0.002 \mathrm{~mol}$ of coumarilic acid prepared in $30 \mathrm{~mL}$ of ethyl alcohol and 0.002 mol of nicotinamide prepared in $30 \mathrm{~mL}$ of water were added separately on them. These solutions were placed in the distillation apparatus and heated with stirring at a temperature between 70 - $80^{\circ} \mathrm{C}$ for 5 hours. After the items were removed from the setup, they were left on hold for a day. Then each substance was taken into separate beakers and placed in the heater, and the mixture of $50 \mathrm{~mL}$ of water and $50 \mathrm{~mL}$ of ethyl alcohol was added over time to evaporate the acetate. During this process, the temperature was tried to be kept between $70-75^{\circ} \mathrm{C}$. The beakers were then sealed with a perforated paraffin film and allowed to stand until the crystal formed. The reaction schemes 
showing the synthesis mechanisms of the coordination compounds are shown in Scheme 1.

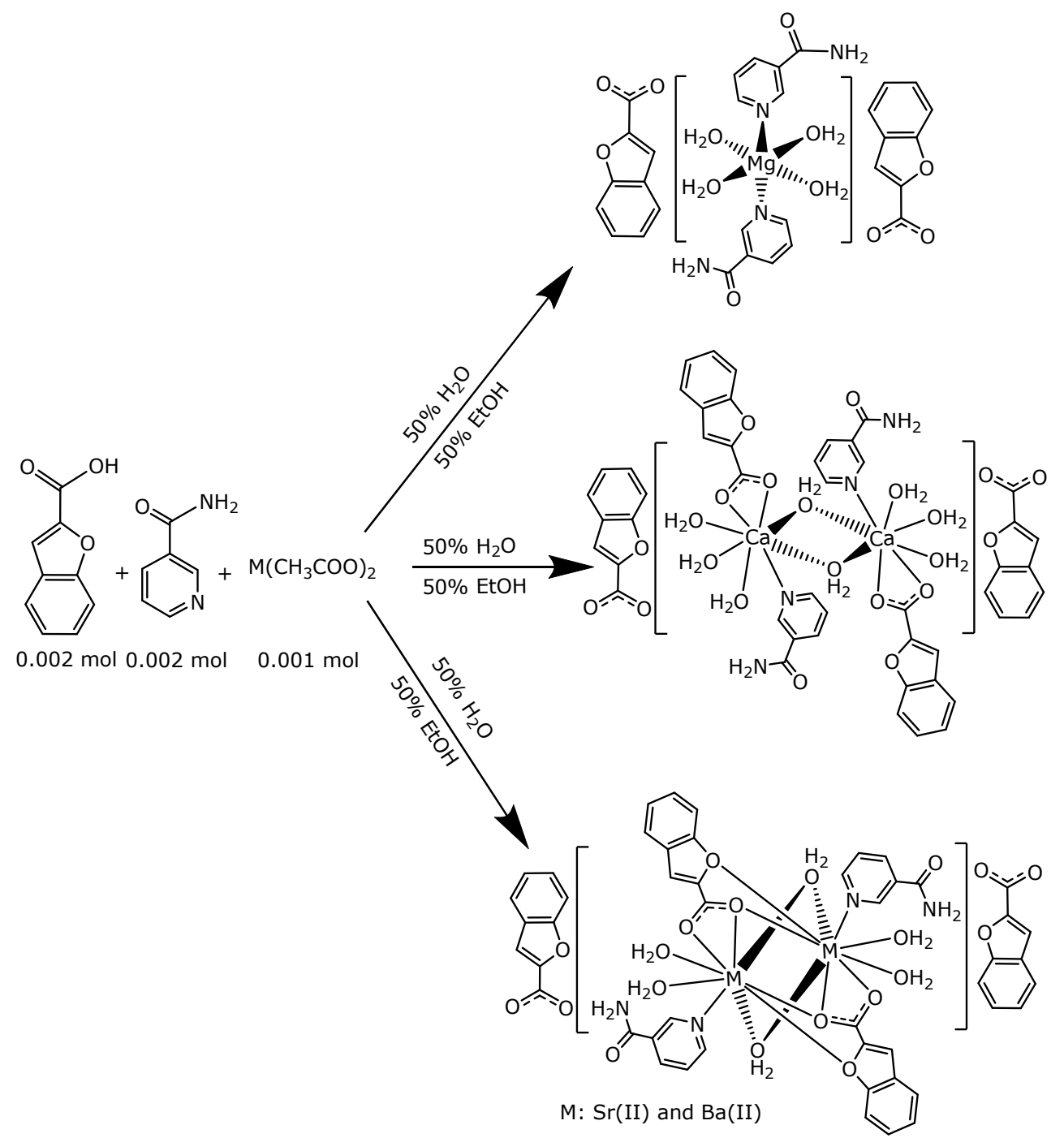

Scheme 1: The synthesis reaction schemes of metal-coumarilate / nicotinamide mixed ligand complexes.

\section{Elemental analysis}

The elemental analysis results of coordination compounds with coumarilate - nicotinamide mixed ligands of alkaline earth metal cations are given in Table 1.

\section{Thermal Analysis}

Thermal analysis curves (TG, DTG, and DTA) showing the thermal behavior of the synthesized alkaline earth metal cations of mixed ligand coordination compounds containing coumarilate / nicotinamide (Figure 2). In addition, the data showing the thermal behavior of the complexes are summarized in Table 2.
The DTG curve of the complex compound of the $\mathrm{Mg}$ (II) cation, which is one of the coumarilate / nicotinamide-containing mixed-ligand complexes of the alkaline earth metal cations, was found to be degraded in four steps corresponding to the maximum temperatures of $125,263,428{ }^{\circ} \mathrm{C}$ and $575 ; 647 ; 758 ; 825^{\circ} \mathrm{C}$.

As the first degradation step, removing uncoordinated hydrate in the structure occurred in the temperature range of $85-147{ }^{\circ} \mathrm{C}$ (exp. 2.65\%; calc. $2.65 \%$ ). Decomposition corresponding to the maximum temperature step at $125{ }^{\circ} \mathrm{C}$ is endothermic.

$$
\left[\mathrm{Mg}\left(\mathrm{C}_{6} \mathrm{H}_{6} \mathrm{~N}_{2} \mathrm{O}\right)_{2}\left(\mathrm{H}_{2} \mathrm{O}\right)_{4}\right] \cdot 2\left(\mathrm{C}_{9} \mathrm{H}_{5} \mathrm{O}_{3}\right) \cdot \mathrm{H}_{2} \mathrm{O} \stackrel{85-147^{\circ} \mathrm{C}}{\longrightarrow}\left[\mathrm{Mg}\left(\mathrm{C}_{6} \mathrm{H}_{6} \mathrm{~N}_{2} \mathrm{O}\right)_{2}\left(\mathrm{H}_{2} \mathrm{O}\right)_{4}\right] \cdot 2\left(\mathrm{C}_{9} \mathrm{H}_{5} \mathrm{O}_{3}\right)+\mathrm{H}_{2} \mathrm{O} \uparrow
$$


The second degradation step is still the dehydrated degradation step and takes place in the temperature range of $158-304{ }^{\circ} \mathrm{C}$. At the $263^{\circ} \mathrm{C}$ DTA peak, the four moles of coordination water remaining in the coordination sphere in the endothermic degradation step decay away (exp. $11.07 \%$; calc. $10.58 \%$ ).

$$
\left[\mathrm{Mg}\left(\mathrm{C}_{6} \mathrm{H}_{6} \mathrm{~N}_{2} \mathrm{O}\right)_{2}\left(\mathrm{H}_{2} \mathrm{O}\right)_{4}\right] \cdot 2\left(\mathrm{C}_{9} \mathrm{H}_{5} \mathrm{O}_{3}\right) \stackrel{158-304^{\circ} \mathrm{C}}{\longrightarrow}\left[\mathrm{Mg}\left(\mathrm{C}_{6} \mathrm{H}_{6} \mathrm{~N}_{2} \mathrm{O}\right)_{2}\right] \cdot 2\left(\mathrm{C}_{9} \mathrm{H}_{5} \mathrm{O}_{3}\right)+4 \mathrm{H}_{2} \mathrm{O} \uparrow
$$

From the coordination compound, which has become entirely dehydrated, in the third degradation step, two moles of nicotinamide (na) ligand in the structure burns and degrades in the temperature range of $351-482{ }^{\circ} \mathrm{C}$. It is thought that $\mathrm{NO} / \mathrm{NO}_{2}, \mathrm{CO} / \mathrm{CO}_{2}$, and $\mathrm{H}_{2} \mathrm{O}$ combustion gases and vapors are formed as decomposition products in the reaction that takes place at $428{ }^{\circ} \mathrm{C}$ maximum decomposition step endothermically (exp. $34.97 \%$; calc. $35.84 \%$ ).

$$
\left[\mathrm{Mg}\left(\mathrm{C}_{6} \mathrm{H}_{6} \mathrm{~N}_{2} \mathrm{O}\right)_{2}\right] \cdot 2\left(\mathrm{C}_{9} \mathrm{H}_{5} \mathrm{O}_{3}\right) \stackrel{351-482^{\circ} \mathrm{C}}{\longrightarrow}[\mathrm{Mg}] \cdot 2\left(\mathrm{C}_{9} \mathrm{H}_{5} \mathrm{O}_{3}\right)+\mathrm{NO} / \mathrm{NO}_{2}+\mathrm{CO} / \mathrm{CO}_{2}+4 \mathrm{H}_{2} \mathrm{O}^{\uparrow}
$$

The last step of decay can be attributed to the separation of the two moles of coumarilate ligands located outside the coordination sphere as the stabilizing ion in the structure in the $485-908{ }^{\circ} \mathrm{C}$ temperature region. Endothermic degradation has DTA peaks at 575; 647; 758; $825{ }^{\circ} \mathrm{C}$ Experimental and theoretical mass losses also support this claim (exp. 44.11\%; calc. 44.94\%).
After this decomposition step, it was determined that the oxide compound of the corresponding metal cation remained in the reaction vessel. The fact that the color of the oxide is black instead of white can be said to be caused by the carbonized carbon remaining in the environment (exp. 7.20\%; calc. $5.92 \%$ ).

$$
[\mathrm{Mg}] .2\left(\mathrm{C}_{9} \mathrm{H}_{5} \mathrm{O}_{3}\right) \stackrel{351-482{ }^{\circ} \mathrm{C}}{\longrightarrow} \mathrm{MgO}+{\mathrm{CO} / \mathrm{CO}_{2}}^{\uparrow}+4 \mathrm{H}_{2} \mathrm{O} \uparrow
$$

DTA curve of the coordination compound with mixed ligands of $\mathrm{Ca}$ metal cation shows that decays occur in four steps, at $118,254,-414$ and $481 ;-688 ; 708{ }^{\circ} \mathrm{C}$ maximum temperatures. The first degradation step is involved in the removal of all aqua ligands in the structure (three moles of aqua at the two-molar bridge position and six moles of aqua ligands in total, three moles attached to each $\mathrm{Ca}$ cation) in the temperature range $65-186{ }^{\circ} \mathrm{C}$. These decays are endothermic and occur at $118{ }^{\circ} \mathrm{C}$ maximum degradation step (exp. $11.98 \%$; calc. $12.94 \%$ ).

$$
\left.\mu-\left(\mathrm{H}_{2} \mathrm{O}\right)_{2}\left[\mathrm{Ca}\left(\mathrm{C}_{9} \mathrm{H}_{5} \mathrm{O}_{3}\right)\left(\mathrm{C}_{6} \mathrm{H}_{6} \mathrm{~N}_{2} \mathrm{O}\right)\left(\mathrm{H}_{2} \mathrm{O}\right)_{3}\right]_{2} \cdot 2\left(\mathrm{C}_{9} \mathrm{H}_{5} \mathrm{O}_{3}\right) \underset{\left[\mathrm{Ca}\left(\mathrm{C}_{9} \mathrm{H}_{5} \mathrm{O}_{3}\right)\right.}{\longrightarrow}\left(\mathrm{C}_{6} \mathrm{H}_{6} \mathrm{~N}_{2} \mathrm{O}\right)\right]_{2} \cdot 2\left(\mathrm{C}_{9} \mathrm{H}_{5} \mathrm{O}_{3}\right)+8 \mathrm{H}_{2} \mathrm{O}
$$

In the temperature range of $188-290{ }^{\circ} \mathrm{C}$, two moles of neutral nicotinamide ligands are located in the coordination sphere at a maximum degradation step of $254^{\circ} \mathrm{C}$ burn away from the structure (exp. 21.93\%; calc. $21.92 \%$ ). It is thought that $\mathrm{NO} / \mathrm{NO}_{2}, \mathrm{CO} / \mathrm{CO}_{2}$, and $\mathrm{H}_{2} \mathrm{O}$ gas and vapors are formed as combustion products.

$$
\left[\mathrm{Ca}\left(\mathrm{C}_{9} \mathrm{H}_{5} \mathrm{O}_{3}\right)\left(\mathrm{C}_{6} \mathrm{H}_{6} \mathrm{~N}_{2} \mathrm{O}\right)\right]_{2} \cdot 2\left(\mathrm{C}_{9} \mathrm{H}_{5} \mathrm{O}_{3}\right) \stackrel{188-290^{\circ} \mathrm{C}}{\longrightarrow}\left[\mathrm{Ca}\left(\mathrm{C}_{9} \mathrm{H}_{5} \mathrm{O}_{3}\right)\right]_{2} \cdot 2\left(\mathrm{C}_{9} \mathrm{H}_{5} \mathrm{O}_{3}\right)+\mathrm{NO} / \mathrm{NO}_{2}{ }^{4}+\mathrm{CO}^{2} \mathrm{CO}_{2}^{\dagger}+\mathrm{H}_{2} \mathrm{O}
$$

The degradation of the two moles of coumarilate ligand, which is located outside the coordination sphere and provides the charge balance of the structure as the counter-ion, occurs in the temperature region of $343-424{ }^{\circ} \mathrm{C}$, exothermic at a maximum decomposition temperature of $-414{ }^{\circ} \mathrm{C}$ (exp. 28.72\%; calc. $28.93 \%$ ).

$$
\left[\mathrm{Ca}\left(\mathrm{C}_{9} \mathrm{H}_{5} \mathrm{O}_{3}\right)\right]_{2} \cdot 2\left(\mathrm{C}_{9} \mathrm{H}_{5} \mathrm{O}_{3}\right) \stackrel{343-424^{\circ} \mathrm{C}}{\longrightarrow}\left[\mathrm{Ca}\left(\mathrm{C}_{9} \mathrm{H}_{5} \mathrm{O}_{3}\right)\right]_{2}+\mathrm{CO}^{-\mathrm{CO}_{2}}+\mathrm{H}_{2} \mathrm{O}^{\uparrow}
$$


The fourth and last degradation step can be attributed to the decomposition of two-mole coumarilate ligands coordinated to the metal cation inside the coordination sphere. Decomposition occurs in the temperature range of $427-905{ }^{\circ} \mathrm{C}$ and at maximum decomposition temperatures of
$481 ;-688 ; 708{ }^{\circ} \mathrm{C}$ provided that one is exothermic. The coherence of the experimental and calculated mass losses attributed to the decay supports the claimed degradation (exp. 25.82\%; calc. $26.06 \%$ ).

$$
\left[\mathrm{Ca}\left(\mathrm{C}_{9} \mathrm{H}_{5} \mathrm{O}_{3}\right)\right]_{2} \stackrel{427-905^{\circ} \mathrm{C}}{\longrightarrow} 2 \mathrm{CaO}+\mathrm{CO} / \mathrm{CO}_{2}^{\uparrow}+\mathrm{H}_{2} \mathrm{O}^{\uparrow}
$$

After all the degradation, the remaining decomposition product is two moles of $\mathrm{CaO}$. The black color of the expected decomposition product in white color can be attributed to the carbonized carbon remaining in the environment due to the inability of complete combustion. This is supported by the fact that the percentage of the experimental residual product is higher than the calculated percentage (exp. $11.55 \%$; calc. $10.06 \%$ ). The thermal analysis curves of the Sr-centered coumarilate/nicotinamide compound determined that six degradation steps correspond to the maximum decomposition temperatures of 85,148 $226,-229,-410 ; 470$ and $-742 ; 848{ }^{\circ} \mathrm{C}$. The first of these is the coordinated four molecule aqua ligand, coordinated at the terminal position to the $\mathrm{Sr}$ cations in the compound in the temperature range $59-106{ }^{\circ} \mathrm{C}$, separated from the structure (exp. $5.83 \%$; calc. $6.14 \%$ ).

$$
\mu-\left(\mathrm{H}_{2} \mathrm{O}\right)_{2}\left[\mathrm{Sr}\left(\mathrm{C}_{9} \mathrm{H}_{5} \mathrm{O}_{3}\right)\left(\mathrm{C}_{6} \mathrm{H}_{6} \mathrm{~N}_{2} \mathrm{O}\right)\left(\mathrm{H}_{2} \mathrm{O}\right)_{2}\right]_{2} \cdot 2\left(\mathrm{C}_{9} \mathrm{H}_{5} \mathrm{O}_{3}\right) \underset{\mu-\left(\mathrm{H}_{2} \mathrm{O}\right)_{2}\left[\mathrm{Sr}\left(\mathrm{C}_{9} \mathrm{H}_{5} \mathrm{O}_{3}\right)\left(\mathrm{C}_{6} \mathrm{H}_{6} \mathrm{~N}_{2} \mathrm{O}\right)\right]_{2} \cdot 2\left(\mathrm{C}_{9} \mathrm{H}_{5} \mathrm{O}_{3}\right)+4 \mathrm{H}_{2} \mathrm{O}^{\dagger}}{\stackrel{59}{\mathrm{C}}}
$$

In the next step of decay, it was determined that the two molecule aqua ligands, which are bridging between the two $\mathrm{Sr}$ atoms, which act as central cations in the structure, were decomposed in the $108-192{ }^{\circ} \mathrm{C}$ temperature range in the $148{ }^{\circ} \mathrm{C}$ DTA max. (exp. $2.72 \%$; calc. $3.07 \%$ ).

$$
\mu-\left(\mathrm{H}_{2} \mathrm{O}\right)_{2}\left[\mathrm{Sr}\left(\mathrm{C}_{9} \mathrm{H}_{5} \mathrm{O}_{3}\right)\left(\mathrm{C}_{6} \mathrm{H}_{6} \mathrm{~N}_{2} \mathrm{O}\right)\right]_{2} \cdot 2\left(\mathrm{C}_{9} \mathrm{H}_{5} \mathrm{O}_{3}\right) \underset{\left[\mathrm{Sr}\left(\mathrm{C}_{9} \mathrm{H}_{5} \mathrm{O}_{3}\right)\right.}{\left.\stackrel{108-192^{\circ} \mathrm{C}}{\longrightarrow}\left(\mathrm{C}_{6} \mathrm{H}_{6} \mathrm{~N}_{2} \mathrm{O}\right)\right]_{2} \cdot 2\left(\mathrm{C}_{9} \mathrm{H}_{5} \mathrm{O}_{3}\right)+2 \mathrm{H}_{2} \mathrm{O}} \uparrow
$$

In the next degradation step, it was determined that the two molecule aqua ligands, which are bridging between the two $\mathrm{Sr}$ atoms, were decomposed in the $108-192{ }^{\circ} \mathrm{C}$ temperature range, in the $148{ }^{\circ} \mathrm{C}$ DTA maximum temperature (exp. $2.72 \%$; calc. $3.07 \%$ ). In the subsequent decomposition stage of the dehydrated complex starts to burn organic residues. Comparing the experimental and calculated mass losses (exp.
$7.31 \%$; calc. $7.51 \%$ ) estimates that partial combustion of the nicotinamide ligand in the neutral position occurs primarily. The carbonyl and amide functional groups of the nicotinamide ligand form $\mathrm{NO} / \mathrm{NO}_{2}, \mathrm{CO} / \mathrm{CO}_{2}$, and $\mathrm{H}_{2} \mathrm{O}$ combustion products and move away from the structure in the $195-282{ }^{\circ} \mathrm{C}$ temperature region, at the maximum decomposition temperature of $226^{\circ} \mathrm{C}$.

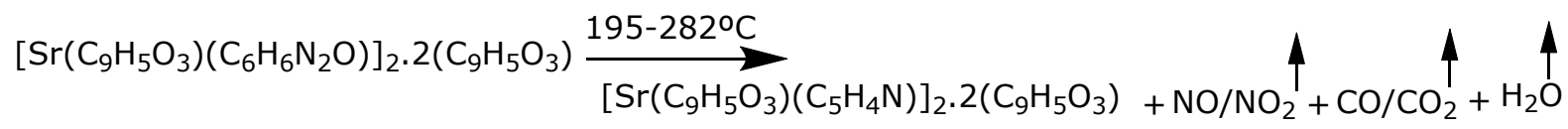


Table 1: Elemental analysis data of molecules.

\begin{tabular}{|c|c|c|c|c|c|}
\hline Complex & $\begin{array}{c}\text { M.A. } \\
(\mathrm{g} / \mathrm{mol})\end{array}$ & $\begin{array}{l}\text { Yield } \\
(\%)\end{array}$ & $\begin{array}{c}\mathrm{C} \% \\
\exp -(\mathrm{calc})\end{array}$ & $\begin{array}{c}H \% \\
\exp -(\text { calc })\end{array}$ & $\begin{array}{c}\mathrm{N} \% \\
\exp -(\text { calc })\end{array}$ \\
\hline $\begin{array}{c}{\left[\mathrm{Mg}\left(\mathrm{C}_{10} \mathrm{H}_{14} \mathrm{~N}_{2} \mathrm{O}\right)_{2}\left(\mathrm{H}_{2} \mathrm{O}\right)_{4}\right] .2\left(\mathrm{C}_{9} \mathrm{H}_{5} \mathrm{O}_{3}\right) . \mathrm{H}_{2} \mathrm{O}(\mathrm{I})} \\
\mu-\left(\mathrm{H}_{2} \mathrm{O}\right)_{2}\left[\mathrm{Ca}\left(\mathrm{C}_{9} \mathrm{H}_{5} \mathrm{O}_{3}\right)\left(\mathrm{C}_{6} \mathrm{H}_{6} \mathrm{~N}_{2} \mathrm{O}\right)\left(\mathrm{H}_{2} \mathrm{O}\right)_{3}\right]_{2.2}\left(\mathrm{C}_{9} \mathrm{H}_{5} \mathrm{O}_{3}\right)(\mathrm{II}) \\
\mu-\left(\mathrm{H}_{2} \mathrm{O}\right)_{2}\left[\mathrm{Sr}\left(\mathrm{C}_{9} \mathrm{H}_{5} \mathrm{O}_{3}\right)\left(\mathrm{C}_{6} \mathrm{H}_{6} \mathrm{~N}_{2} \mathrm{O}\right)\left(\mathrm{H}_{2} \mathrm{O}\right)_{2}\right]_{2.2}\left(\mathrm{C}_{9} \mathrm{H}_{5} \mathrm{O}_{3}\right) \text { (III) } \\
\mu-\left(\mathrm{H}_{2} \mathrm{O}\right)_{2}\left[\mathrm{Ba}\left(\mathrm{C}_{9} \mathrm{H}_{5} \mathrm{O}_{3}\right)\left(\mathrm{C}_{6} \mathrm{H}_{6} \mathrm{~N}_{2} \mathrm{O}\right)\left(\mathrm{H}_{2} \mathrm{O}\right)_{2}\right]_{2.2}\left(\mathrm{C}_{9} \mathrm{H}_{5} \mathrm{O}_{3}\right)(\mathrm{IV})\end{array}$ & $\begin{array}{l}662.89 \\
1113.07 \\
1172.13 \\
1271.54\end{array}$ & $\begin{array}{l}91 \\
90 \\
87 \\
86\end{array}$ & $\begin{array}{l}53.92-(54.36) \\
51.33-(51.80) \\
48.77-(49.19) \\
45.73-(45.34)\end{array}$ & $\begin{array}{l}4.77-(4.56) \\
4.71-(4.35) \\
3.92-(3.78) \\
3.79-(3.49)\end{array}$ & $\begin{array}{l}8.32-(8.45) \\
4.97-(5.03) \\
4.84-(4.78) \\
4.35-(4.41)\end{array}$ \\
\hline
\end{tabular}


Subsequent degradation has been attributed to the burning of the more stable pyridine rings of nicotinamide ligands. In the temperature range of $372-403{ }^{\circ} \mathrm{C}$, in the exothermic $-299{ }^{\circ} \mathrm{C}$ decomposition step, the pyridine rings remove from the structure by giving the combustion gases and vapors of $\mathrm{NO} / \mathrm{NO}_{2}, \mathrm{CO} / \mathrm{CO}_{2}$, and $\mathrm{H}_{2} \mathrm{O}$ (exp. $13.51 \%$; calc. $13.31 \%)$.

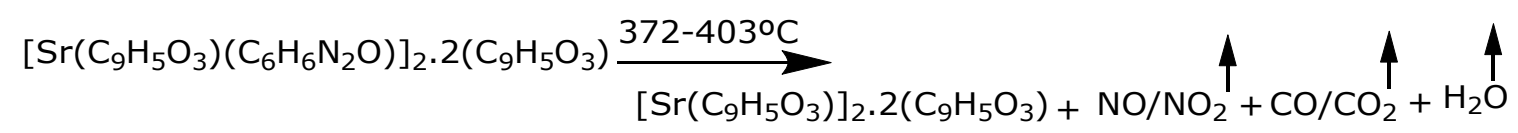

The combustion reactions taking place in the degradation steps in the temperature range of 404-685 ${ }^{\circ} \mathrm{C}$, one exothermic $-410{ }^{\circ} \mathrm{C}$, and the other endothermic $470{ }^{\circ} \mathrm{C}$, can be attributed to two mole stabilizing coumarilate anions located outside the coordination sphere. The compatibility of experimental and theoretical results with each other also supports this situation (exp. 26.92\%; calc. $27.47 \%$ ).

$$
\left[\mathrm{Sr}\left(\mathrm{C}_{9} \mathrm{H}_{5} \mathrm{O}_{3}\right)\right]_{2} \cdot 2\left(\mathrm{C}_{9} \mathrm{H}_{5} \mathrm{O}_{3}\right) \stackrel{404-685^{\circ} \mathrm{C}}{\longrightarrow}\left[\mathrm{Sr}\left(\mathrm{C}_{9} \mathrm{H}_{5} \mathrm{O}_{3}\right)\right]_{2}+\mathrm{CO} / \mathrm{CO}_{2}+\mathrm{H}_{2} \mathrm{O}
$$

The sixth and final degradation step is the step in which all combustion events occur, and the degradation ends, and the last black-colored molecule of SrO remains. The coherence of experimental and theoretical mass losses in the combustion reaction occurring at the maximum decomposition temperatures of $742{ }^{\circ} \mathrm{C}$ and endothermic $848{ }^{\circ} \mathrm{C}$ in the $687-891{ }^{\circ} \mathrm{C}$ temperature region also supports this result (exp. $24.91 \%$; calc. $24.74 \%$ ). It is suggested that
$\mathrm{CO} / \mathrm{CO}_{2}$ and $\mathrm{H}_{2} \mathrm{O}$ combustion gas and vapors are formed as combustion products. The fact that the experimental mass amount of the final residual product is slightly higher than the theoretical amount indicates that the black color of the residual product is due to carbonized carbon remaining from combustion due to an inert nitrogen environment (exp. 18.80\%; calc. $17.68 \%)$.

$$
\left[\mathrm{Sr}\left(\mathrm{C}_{9} \mathrm{H}_{5} \mathrm{O}_{3}\right)\right]_{2} \stackrel{687-891^{\circ} \mathrm{C}}{\longrightarrow} 2 \mathrm{SrO}+\mathrm{CO} / \mathrm{CO}_{2}+\mathrm{H}_{2} \mathrm{O}
$$

Thermal analysis curves of the coumarilate / nicotinamide complex of the $\mathrm{Ba}$ metal cation are given in Figure 4. Six degradation steps were observed in the DTA curve at maximum decomposition temperatures of $86,205,333$, $401,-417 ; 454 ; 617$ and $-707 ;-774 ; 842{ }^{\circ} \mathrm{C}$. The degradation pattern of the $\mathrm{Ba}$ complex is very similar to that of the Sr complex. The first decay step can be attributed to the removal of the coordinated four molecules of aqua ligand at the terminal position to the $\mathrm{Ba}$ cations in the temperature range $59-94{ }^{\circ} \mathrm{C}$ (exp. 6.02\%; calc. $5.66 \%)$.

$$
\mu-\left(\mathrm{H}_{2} \mathrm{O}\right)_{2}\left[\mathrm{Ba}\left(\mathrm{C}_{9} \mathrm{H}_{5} \mathrm{O}_{3}\right)\left(\mathrm{C}_{6} \mathrm{H}_{6} \mathrm{~N}_{2} \mathrm{O}\right)\left(\mathrm{H}_{2} \mathrm{O}\right)_{2}\right]_{2} \cdot 2\left(\mathrm{C}_{9} \mathrm{H}_{5} \mathrm{O}_{3}\right) \stackrel{59-94^{\circ} \mathrm{C}}{\longrightarrow} \underset{\mu-\left(\mathrm{H}_{2} \mathrm{O}\right)_{2}\left[\mathrm{Ba}\left(\mathrm{C}_{9} \mathrm{H}_{5} \mathrm{O}_{3}\right)\left(\mathrm{C}_{6} \mathrm{H}_{6} \mathrm{~N}_{2} \mathrm{O}\right)\right]_{2} \cdot 2\left(\mathrm{C}_{9} \mathrm{H}_{5} \mathrm{O}_{3}\right)+4 \mathrm{H}_{2} \mathrm{O}}{\uparrow}
$$

The second degradation step is still the dehydrated degradation step and belongs to the degradation of the aqua ligands, which are the bridges connecting the two $\mathrm{Ba}$ cations, which takes place in the temperature range $95-215{ }^{\circ} \mathrm{C}$ with a maximum decomposition temperature of $86^{\circ} \mathrm{C}$ (exp. 3.04\%; calc. $2.83 \%$ ).

$$
\left.\mu^{-}\left(\mathrm{H}_{2} \mathrm{O}\right)_{2}\left[\mathrm{Ba}\left(\mathrm{C}_{9} \mathrm{H}_{5} \mathrm{O}_{3}\right)\left(\mathrm{C}_{6} \mathrm{H}_{6} \mathrm{~N}_{2} \mathrm{O}\right)\right]_{2} \cdot 2\left(\mathrm{C}_{9} \mathrm{H}_{5} \mathrm{O}_{3}\right) \frac{95-215^{\circ} \mathrm{C}}{\left[\mathrm{Ba}\left(\mathrm{C}_{9} \mathrm{H}_{5} \mathrm{O}_{3}\right)\right.}\left(\mathrm{C}_{6} \mathrm{H}_{6} \mathrm{~N}_{2} \mathrm{O}\right)\right]_{2} \cdot 2\left(\mathrm{C}_{9} \mathrm{H}_{5} \mathrm{O}_{3}\right)+2 \mathrm{H}_{2} \mathrm{O}^{\dagger}
$$

It is thought that the neutral ligand, nicotinamide $\mathrm{NH}_{2}$ group, leaves the structure in the form of ammonia gas in the next decaying step of the dehydrated coordination compound, with the water 
removed from its structure. The decomposition's experimental and theoretical mass losses in the temperature range of $217-384{ }^{\circ} \mathrm{C}$ are consistent with this fragmentation (exp. 2.42.04\%; calc. $2.52 \%)$.

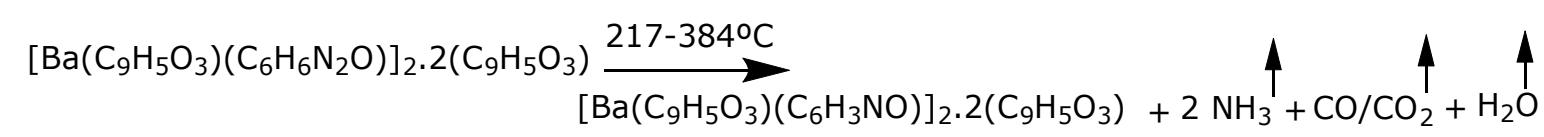

The subsequent degradation belongs to the combustion reaction of the remaining parts of nicotinamide ligands, leaving the structure by forming $\mathrm{NO} / \mathrm{NO}_{2}, \mathrm{CO} / \mathrm{CO}_{2}$, and $\mathrm{H}_{2} \mathrm{O}$ combustion products. In the temperature range of $385-407^{\circ} \mathrm{C}$, in the exothermic $-401{ }^{\circ} \mathrm{C}$ degradation step, the nicotinamide residue burns completely (exp. $16.52 \%$; calc. $16.67 \%)$.

$$
\left[\mathrm{Ba}\left(\mathrm{C}_{9} \mathrm{H}_{5} \mathrm{O}_{3}\right)\left(\mathrm{C}_{6} \mathrm{H}_{3} \mathrm{NO}\right)\right]_{2} \cdot 2\left(\mathrm{C}_{9} \mathrm{H}_{5} \mathrm{O}_{3}\right) \stackrel{385-407^{\circ} \mathrm{C}}{\longrightarrow}\left[\mathrm{Ba}\left(\mathrm{C}_{9} \mathrm{H}_{5} \mathrm{O}_{3}\right)\right]_{2} \cdot 2\left(\mathrm{C}_{9} \mathrm{H}_{5} \mathrm{O}_{3}\right)+\mathrm{NO} / \mathrm{NO}_{2}+\mathrm{CO}_{2} \mathrm{CO}_{2}+\mathrm{H}_{2} \mathrm{O}^{\uparrow}
$$

The degradation continues with the combustion of the coumarilate anions in the counter-ion position outside the coordination sphere, among the four molecule coumarilate ligands, which are organic residues in the structure. In the temperature range of $408-580{ }^{\circ} \mathrm{C}$, one exothermic $-410{ }^{\circ} \mathrm{C}$, others endothermic $454 ; 617{ }^{\circ} \mathrm{C}$ decomposition products are formed as a result of the combustion reactions that take place in the decomposition steps (exp. $25.22 \%$; calc. $25.33 \%$ ).

$$
\left[\mathrm{Ba}\left(\mathrm{C}_{9} \mathrm{H}_{5} \mathrm{O}_{3}\right)\right]_{2} \cdot 2\left(\mathrm{C}_{9} \mathrm{H}_{5} \mathrm{O}_{3}\right) \stackrel{408-580^{\circ} \mathrm{C}}{\longrightarrow}\left[\mathrm{Ba}\left(\mathrm{C}_{9} \mathrm{H}_{5} \mathrm{O}_{3}\right)\right]_{2}+\mathrm{CO} / \mathrm{CO}_{2}+\mathrm{H}_{2} \mathrm{O}
$$

The final degradation step of the thermal analysis of the complex occurs in the temperature region of 585-880 ${ }^{\circ} \mathrm{C}$, while it takes place in three steps, two exothermic $-707 ;-774{ }^{\circ} \mathrm{C}$ and the other endothermic $842{ }^{\circ} \mathrm{C}$. After all the combustion and disintegration processes, it was determined that $25.21 \% \mathrm{BaO}$ residue remained in the reaction vessel as the final product. The fact that this value is slightly higher than the theoretically calculated residual value $(24.12 \%)$ is that complete combustion cannot occur by conditioning the reaction medium with inert nitrogen gas to determine the disintegration steps more clearly since complete combustion could not take place, some carbon residue accumulated on the surface of the metal oxide as carbonized coal, which can be interpreted as the reason for the expected black color of the residual metal oxide.

$$
\left[\mathrm{Ba}\left(\mathrm{C}_{9} \mathrm{H}_{5} \mathrm{O}_{3}\right)\right]_{2} \stackrel{585-880^{\circ} \mathrm{C}}{\longrightarrow} 2 \mathrm{BaO}+\mathrm{CO} / \mathrm{CO}_{2}+\mathrm{H}_{2} \mathrm{O}
$$




\section{Infrared spectroscopy}

FTIR stretching modes of the coumarilic acid/nicotinamide complexes of alkaline earth metal cations are given in Figure 3, and the important band stretching modes of the FT-IR spectra of the compounds are summarized in Table 4.

When FTIR spectra of alkaline earth metal cation complexes with mixed ligands containing coumarilate / nicotinamide ligands are examined, the resulting strong and broadband $3680-2850 \mathrm{~cm}^{-1}$ indicates the presence of $-\mathrm{OH}$ group in the structures of the coordination compounds. The $\mathrm{Mg}$ metal cation complex is salt type, and the coumarilate ligands are located outside the coordination sphere. In other structures, coumarilate ligands entered the coordination sphere. Accordingly, different FTIR peaks were observed in the $\mathrm{Mg}$ cation mixed ligand complex from other structures. While the peak of the $\mathrm{C}=\mathrm{O}$ stress vibration of the carboxylic acid group in the $\mathrm{Mg}$ complex is observed at $1663 \mathrm{~cm}^{-1}$, it is also understood from the difference between asymmetric and symmetrical stress vibrations that the same group is monodentately coordinated $(\mathrm{v}(\mathrm{C}=\mathrm{O})$ asym.$\mathrm{v}(\mathrm{C}=\mathrm{O})_{\text {sym. }}: 1562 \mathrm{~cm}^{-1}-1441 \mathrm{~cm}^{-1}=\Delta \mathrm{V}_{\text {asym-sym }}: 121$ $\left.\mathrm{cm}^{-1}\right)$. In other complexes, the bonding is of bidentate fashion, and the differences between asymmetric and symmetrical stress vibrations are found to be greater than the difference $\left(130 \mathrm{~cm}^{-1}\right)$ between the coumarilic acid's own asymmetric and symmetrical stress vibrations $\left(170 \mathrm{~cm}^{-1}\right.$ for complex II, $142 \mathrm{~cm}^{-1}$ for complex III, $160 \mathrm{~cm}^{-1}$ for complex IV respectively). The appearance of both the $\mathrm{N}-\mathrm{H}$ peaks of the nicotinamide ligand and the fact that the peaks of the carbonyl group of the amide group do not show any shift compared to the pure nicotinamide ligand can be considered as evidence that this ligand participates in the coordination via the characteristic pyridine nitrogen. The peaks belonging to the coordination of the ligands are generally the peaks indicating the attachment to the metal center. In contrast, three different coordination is observed in the $\mathrm{Mg}$ complex, which is different from the other compounds $\left(649 \mathrm{~cm}^{-1}\right.$ for

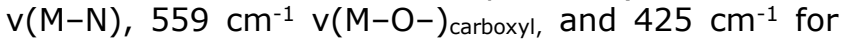
$\left.\mathrm{v}(\mathrm{M}-\mathrm{O})_{\text {aqua }}\right)$, while in the other three cation complexes, four different coordination with the metal was observed due to the carboxylate group oxygens that show bidentate bonding. The stresses belonging to these coordinations have been found for the Ca complex $\mathrm{v}(\mathrm{M}-\mathrm{N})$ is $646 \mathrm{~cm}^{-1}, \mathrm{v}(\mathrm{M}-$ $\mathrm{O}-)_{\text {carboxyl }}$ is $581 \mathrm{~cm}^{-1}, \mathrm{v}(\mathrm{M}-\mathrm{O}=)_{\text {carbonyl }} 535 \mathrm{~cm}^{-1}$ and $\mathrm{v}(\mathrm{M}-\mathrm{O})$ aqua $427 \mathrm{~cm}^{-1}$; for the Sr complex $\mathrm{v}(\mathrm{M}-\mathrm{N})$ is $617 \mathrm{~cm}^{-1}, \mathrm{v}(\mathrm{M}-\mathrm{O}-)_{\text {carboxyl }} 578 \mathrm{~cm}^{-1}, \mathrm{v}(\mathrm{M}-\mathrm{O}=)_{\text {carbonyl }}$ $526 \mathrm{~cm}^{-1}$ and $\mathrm{V}(\mathrm{M}-\mathrm{O})$ aqua $445 \mathrm{~cm}^{-1}$; for the $\mathrm{Ba}$ complex $\mathrm{v}(\mathrm{M}-\mathrm{N})$ is $669 \mathrm{~cm}^{-1}, \mathrm{v}(\mathrm{M}-\mathrm{O}-)_{\text {carboxyl }}$ is 581 $\mathrm{cm}^{-1}, \mathrm{v}(\mathrm{M}-\mathrm{O}=)_{\text {carbonyl }} 526 \mathrm{~cm}^{-1}$ and $\mathrm{v}(\mathrm{M}-\mathrm{O})$ aqua 426 $\mathrm{cm}^{-1}$. 

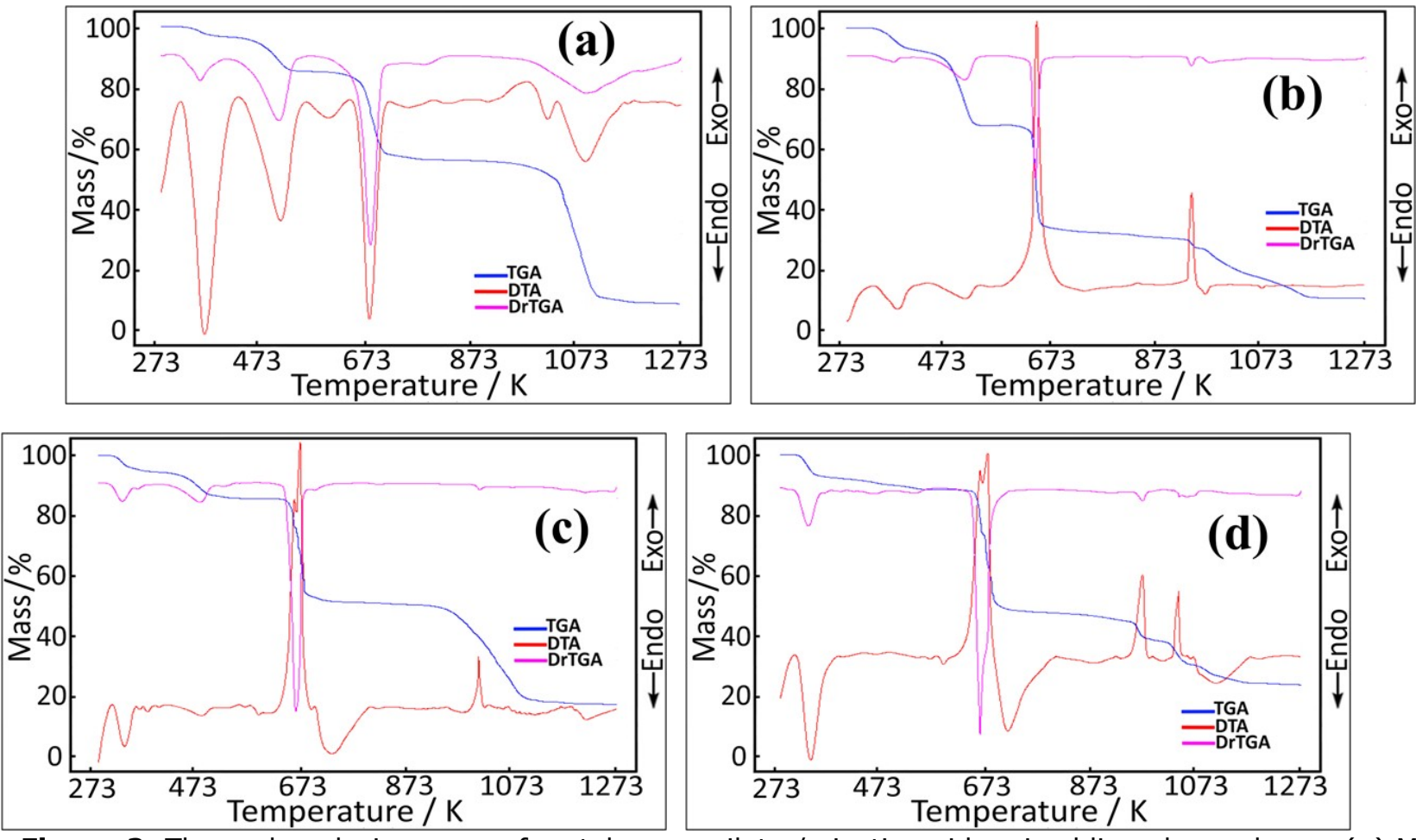

Figure 2: Thermal analysis curves of metal-coumarilate / nicotinamide mixed ligand complexes. (a) $\mathrm{Mg}^{2+}$ complex, (b) $\mathrm{Ca}^{2+}$ complex, (c) $\mathrm{Sr}^{2+}$ complex and (d) $\mathrm{Ba}^{2+}$ complex.

\section{Powder x-ray diffraction analysis}

It has been determined that all of the molecules whose powder X-ray diffraction patterns are formed have good crystallinities (Figure 4). However, single-crystal structure analysis could not be made due to the small size of the crystals selected for single-crystal structure analysis. The apparent difference in the powder $x$-ray diffraction pattern of the $\mathrm{Mg}^{2+}$ cation-centered complex from that of the other three complexes supports this molecule's proposed salt structure claim. The general similarity of powder X-ray diffraction patterns in $\mathrm{Ca}^{2+}, \mathrm{Sr}^{2+}$, and $\mathrm{Ba}^{2+}$-centered structures strengthens the suggestion that these three structures are isostructural with each other. 
Table 2: Thermal analysis data of metal-coumarilate / nicotinamide mixed ligand complexes.

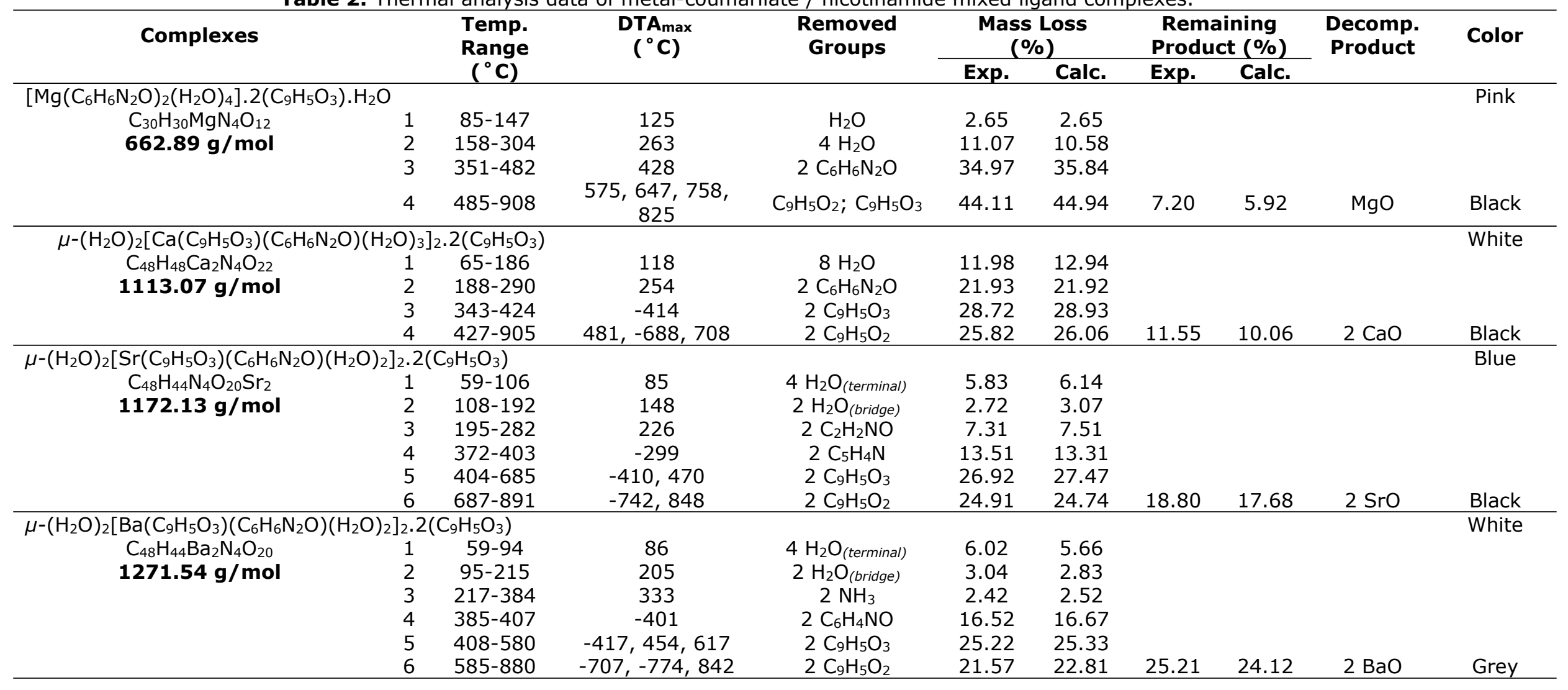




\section{CONCLUSIONS}

This study was presented as a master's thesis, complex compounds with coumarilic acid / nicotinamide mixed ligands of magnesium, calcium, strontium, and barium cations are alkaline earth metal cations, were synthesized. Elemental analysis, Fourier transform infrared spectroscopy (FTIR), thermogravimetric analysis (TGA/DTA), powder $x$ ray diffraction diffractometer ( $P-X R D)$, and melting point determination methods were used to examine the structural characterization of the complexes. It was determined that compounds with mixed ligands were 1:2:1 except for the $\mathrm{Mg}$ complex. In the $\mathrm{Mg}$ complex, the ratio was determined as $1: 2: 2$. Molecular formulas of the compounds determined to contain water in their structures according to thermal analysis curves and infrared spectra are proposed as follows by chemical composition analysis.
(I) $\quad\left[\mathrm{Mg}\left(\mathrm{C}_{6} \mathrm{H}_{6} \mathrm{~N}_{2} \mathrm{O}\right)_{2}\left(\mathrm{H}_{2} \mathrm{O}\right)_{4}\right] \cdot 2\left(\mathrm{C}_{9} \mathrm{H}_{5} \mathrm{O}_{3}\right) \cdot \mathrm{H}_{2} \mathrm{O}$
(II) $\quad \mu-\left(\mathrm{H}_{2} \mathrm{O}\right)_{2}\left[\mathrm{Ca}\left(\mathrm{C}_{9} \mathrm{H}_{5} \mathrm{O}_{3}\right)\left(\mathrm{C}_{6} \mathrm{H}_{6} \mathrm{~N}_{2} \mathrm{O}\right)\left(\mathrm{H}_{2} \mathrm{O}\right)_{3}\right]_{2} .2\left(\mathrm{C}_{9} \mathrm{H}_{5} \mathrm{O}_{3}\right)$
(III) $\mu-\left(\mathrm{H}_{2} \mathrm{O}\right)_{2}\left[\mathrm{Sr}\left(\mathrm{C}_{9} \mathrm{H}_{5} \mathrm{O}_{3}\right)\left(\mathrm{C}_{6} \mathrm{H}_{6} \mathrm{~N}_{2} \mathrm{O}\right)\left(\mathrm{H}_{2} \mathrm{O}\right)_{2}\right]_{2} .2\left(\mathrm{C}_{9} \mathrm{H}_{5} \mathrm{O}_{3}\right)$
$\mathrm{C}_{30} \mathrm{H}_{30} \mathrm{MgN}_{4} \mathrm{O}_{12}$
(IV) $\quad \mu-\left(\mathrm{H}_{2} \mathrm{O}\right)_{2}\left[\mathrm{Ba}\left(\mathrm{C}_{9} \mathrm{H}_{5} \mathrm{O}_{3}\right)\left(\mathrm{C}_{6} \mathrm{H}_{6} \mathrm{~N}_{2} \mathrm{O}\right)\left(\mathrm{H}_{2} \mathrm{O}\right)_{2}\right]_{2} \cdot 2\left(\mathrm{C}_{9} \mathrm{H}_{5} \mathrm{O}_{3}\right)$
$\mathrm{C}_{48} \mathrm{H}_{48} \mathrm{Ca}_{2} \mathrm{~N}_{4} \mathrm{O}_{22}$
$\mathrm{C}_{48} \mathrm{H}_{44} \mathrm{~N}_{4} \mathrm{O}_{20} \mathrm{Sr}_{2}$
$\mathrm{C}_{48} \mathrm{H}_{44} \mathrm{Ba}_{2} \mathrm{~N}_{4} \mathrm{O}_{20}$

Table 3: FT-IR spectral data of metal-coumarilate / nicotinamide mixed ligand complexes.

\begin{tabular}{|c|c|c|c|c|}
\hline Groups & $\mathbf{M g}^{2+}$ & $\mathrm{Ca}^{2+}$ & $\mathbf{S r}^{2+}$ & $\mathbf{B a}^{2+}$ \\
\hline $\mathrm{v}(\mathrm{OH})_{\mathrm{H} 2 \mathrm{O}}$ & $3500-3100$ & $3550-2850$ & $3670-3000$ & $3680-3000$ \\
\hline $\mathbf{v}(\mathbf{N}-\mathbf{H})_{\text {amide }}$ & 3358, 3198 & 3354,2850 & 3498,3180 & 3423, 3175 \\
\hline & 3252 & 3257 & 3280 & 3280 \\
\hline $\mathbf{v}(\mathbf{C}=\mathbf{C}) \mathrm{ar}$ & 3061 & 3061,3081 & 3058,3001 & 3061,3011 \\
\hline $\mathrm{v}\left(\mathrm{CH}_{2}\right)$ & 2910,2825 & 2850,2885 & 2924, 2872 & 2928,2866 \\
\hline $\mathbf{v}(\mathrm{C}=\mathbf{0})_{\text {carbonyl }}$ & 1663 & 1657 & 1643 & 1649 \\
\hline $\mathbf{v}(\mathrm{C}=\mathbf{0})_{\text {amide }}$ & 1705 & 1709 & 1699 & 1697 \\
\hline v(COO-) asym. & 1562 & 1566 & 1552 & 1572 \\
\hline $\mathrm{v}(\mathrm{COO}-)_{\text {sym. }}$ & 1441 & 1396 & 1410 & 1412 \\
\hline$\Delta \mathbf{V}_{\text {as-s }}$ & 121 & 170 & 142 & 160 \\
\hline$\delta(\mathrm{OH})_{\mathrm{H} 2 \mathrm{O}}$ & 1474 & 1467 & 1474 & 1474 \\
\hline $\mathbf{v}(\mathrm{C}-\mathrm{N}-\mathrm{C})_{\text {pyridine }}$ & 1328 & 1334 & 1337 & 1337 \\
\hline$v\left(C_{9}-O_{1}-C_{1}\right)$ & $1259 / 1184$ & $1262 / 1178$ & $1259 / 1178$ & $1262 / 1181$ \\
\hline v(C-O) carboxyl & 1298 & 1295 & 1305 & 1308 \\
\hline v(Ring) & $1106-816$ & $1125-812$ & $1109-835$ & $1109-835$ \\
\hline $\mathbf{v}(\mathbf{C}-\mathbf{N})$ amide & $943-741$ & $943-744$ & $943-741$ & $943-741$ \\
\hline $\mathbf{v}(\mathbf{M}-\mathbf{N})$ & 649 & 646 & 617 & 669 \\
\hline $\mathbf{v}(\mathbf{M}-\mathrm{O}-)_{\text {carboxyl }}$ & 559 & 581 & 578 & 581 \\
\hline $\mathbf{v}(\mathbf{M - O}=)$ & - & 535 & 526 & 526 \\
\hline $\mathbf{v}(\mathbf{M}-\mathbf{O}-)_{\text {aqua }}$ & 425 & 427 & 445 & 426 \\
\hline
\end{tabular}




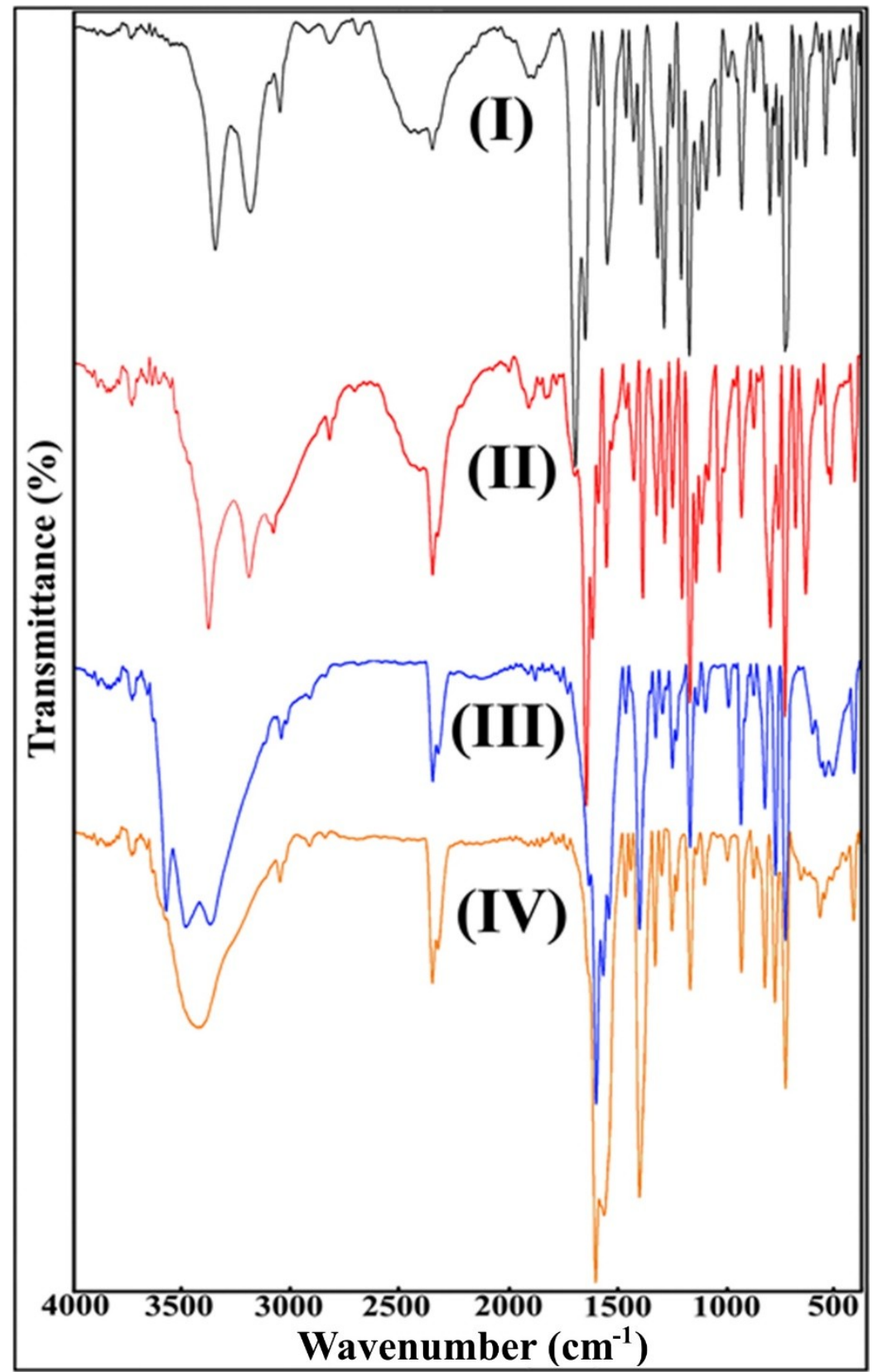

Figure 3. FT-IR spectra of the complex structures I, II, III and IV. 


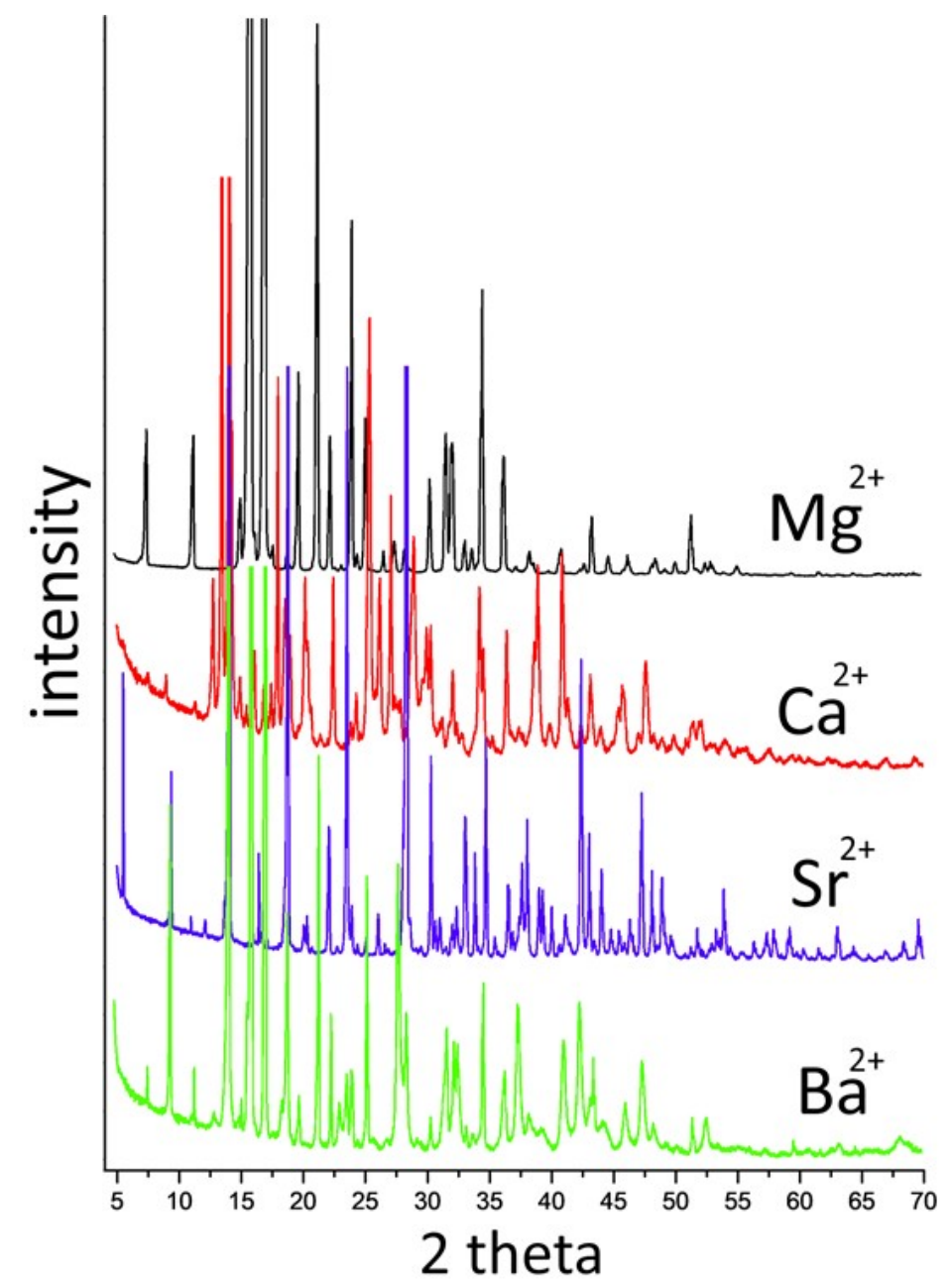

Figure 4: $\mathrm{P}-\mathrm{XRD}$ patterns of the complex structures $\mathrm{Mg}^{2+}, \mathrm{Ca}^{2+}, \mathrm{Sr}^{2+}$ and $\mathrm{Ba}^{2+}$.

The images of the synthesized complexes taken with light microscopy were given in Figure 5. The $\mathrm{Mg}^{2+}$ complex is salt-type, and the coumarilate ligands are located outside the coordination sphere. In other structures, coumarin ligands entered the coordination sphere. Accordingly, different infrared peaks were observed in the $\mathrm{Mg}^{2+}$ cation mixed ligand complex from other structures. The appearance of both the $\mathrm{N}-\mathrm{H}$ peaks of the nicotinamide ligand and the fact that the peaks of the carbonyl group of the amide group do not show any shift compared to the pure nicotinamide ligand can be considered as evidence that this ligand participates in the coordination via the characteristic pyridine nitrogen. The coordination of the ligands is generally supported by infrared peaks that signal their bonding to the metal center. While three different coordination is observed in the $\mathrm{Mg}^{2+}$ complex, which is different from other compounds in its structure, in the other three cation complexes $\left(\mathrm{Ca}^{2+}, \mathrm{Sr}^{2+}\right.$, and $\left.\mathrm{Ba}^{2+}\right)$, the infrared peak of four different coordination with the metal has been determined due to the carboxylate group oxygens showing bidentate bonding. Thermal degradation analysis of the coordination compounds of the synthesized alkaline earth metal cations has been interpreted in detail in the thermal analysis section. The degradation steps started with removing hydrate waters located outside the coordination sphere and continued with the decay of the terminal waters located within the coordination sphere. The complete dehydration of the complexes ended with the departure of the aqua ligands, which were bridging between the two metal cation centers, from the structures. The degradation of organic ligands started with the decomposition of the neutral ligand, nicotinamide, and then continued with the burning of the coumarilic acid ligands. The cleavage sequence of coumarilic acid ligands showing two different types of binding in the complexes was also noticed. First of all, the coumarilate ligands acting as the stabilizing anion of the complexes located outside the coordination sphere have been removed. Afterward, the degradation of the coumarilate ligands that provide bidentate coordination to the metal in the coordination sphere was observed. It was determined that oxide compounds of the respective metals remained in the reaction vessel as the final products of all thermal degradation. 

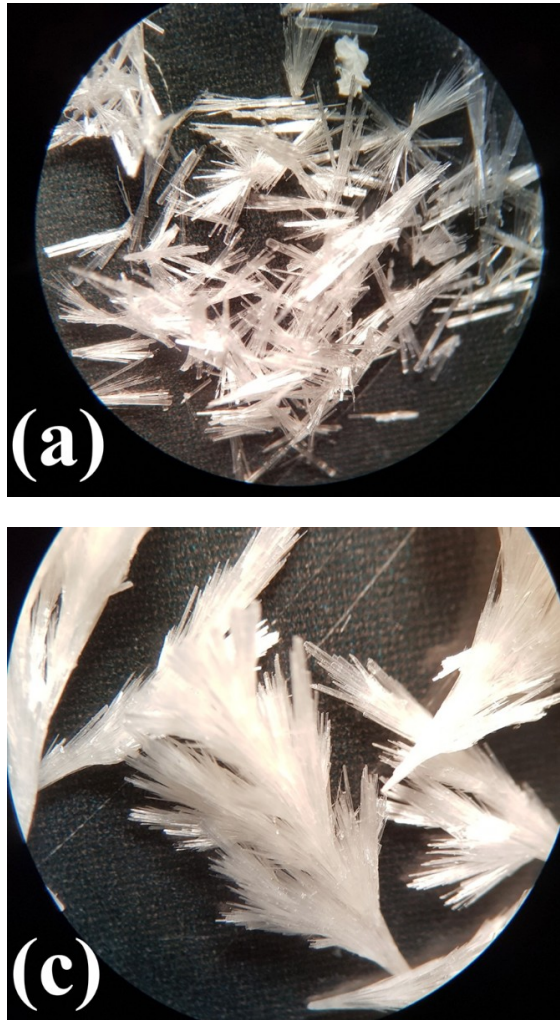
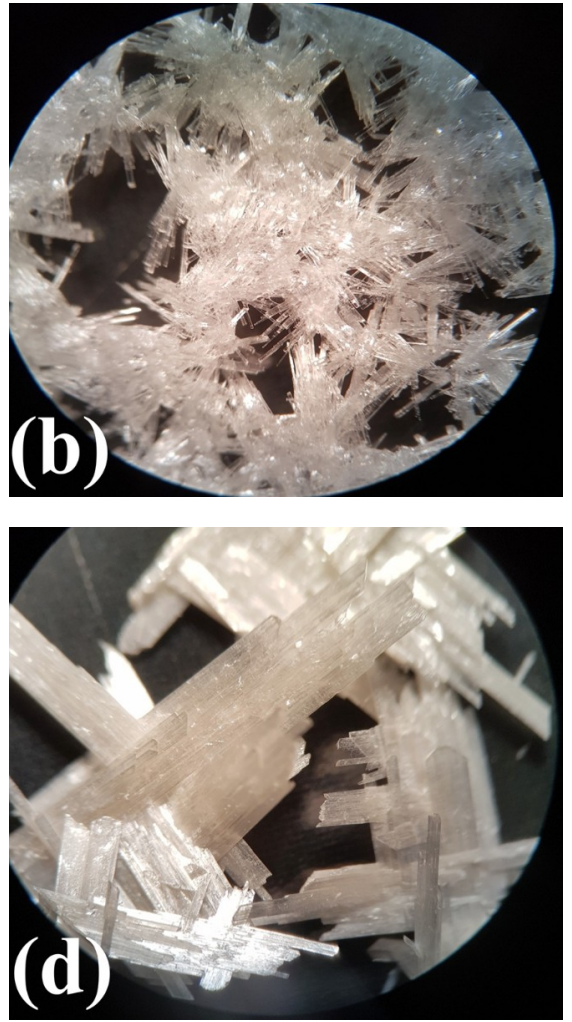

Figure 5: Light microscopic images of the synthesized complexes. (a) $\mathrm{Mg}^{2+}$ complex, (b) $\mathrm{Ca}^{2+}$ complex, (c) $\mathrm{Sr}^{2+}$ complex and (d) $\mathrm{Ba}^{2+}$ complex.

\section{ACKNOWLEDGMENTS}

This study was financially supported by Hitit University in Turkey (Project No. FEF19004.18.001).

\section{REFERENCES}

1. Bosshard $\mathrm{P}$, Eugster $\mathrm{CH}$. The development of the chemistry of furans, 1952-1963. In: Advances in Heterocyclic Chemistry [Internet]. Elsevier; 1967 [cited 2021 May 10]. p. 377-490. Available from: https://linkinghub.elsevier.com/retrieve/pii/S00652 72508605942

2. Khanam H, Shamsuzzaman. Bioactive Benzofuran derivatives: A review. European Journal of Medicinal Chemistry. 2015 Jun;97:483-504. Doi: https://doi.org/10.1016/j.ejmech.2014.11.039.

3. Hiremath SM, Suvitha A, Patil NR, Hiremath CS, Khemalapure SS, Pattanayak SK, et al. Molecular structure, vibrational spectra, NMR, UV, NBO, NLO, HOMO-LUMO and molecular docking of 2-(4, 6dimethyl-1-benzofuran-3-yl) acetic acid (2DBAA): Experimental and theoretical approach. Journal of Molecular Structure. 2018 Nov;1171:362-74. Doi: https://doi.org/10.1016/j.molstruc.2018.05.109.

4. Radadiya A, Shah A. Bioactive benzofuran derivatives: An insight on lead developments, radioligands and advances of the last decade. European Journal of Medicinal Chemistry. 2015 Jun;97:356-76.

Doi: https://doi.org/10.1016/j.ejmech.2015.01.021.

5. Dawood KM. Benzofuran derivatives: a patent review. Expert Opinion on Therapeutic Patents. 2013 Sep;23(9):1133-56. Doi: https://doi.org/10.1517/13543776.2013.801455.

6. Naik R, Harmalkar DS, Xu X, Jang $K$, Lee $\mathrm{K}$. Bioactive benzofuran derivatives: Moracins $A-Z$ in medicinal chemistry. European Journal of Medicinal Chemistry. 2015 Jan;90:379-93. Doi: https://doi.org/10.1016/j.ejmech.2014.11.047.

7. Oka T. Enantioselective synthesis and absolute configuration of (-)-1-(benzofuran-2-yl)-2propylaminopentane, ((-)-BPAP), a highly potent and selective catecholaminergic activity enhancer. Bioorganic \& Medicinal Chemistry. 2001 May;9(5):1213-9. Doi : https://doi.org/10.1016/S0968-0896(00)00341-2.

8. Fukai $T$, Oku Y, Hano $Y$, Terada S. Antimicrobial Activities of Hydrophobic 2-Arylbenzofurans and an Isoflavone against Vancomycin-Resistant Enterococci and Methicillin-Resistant Staphylococcus aureus. Planta med. 2004 Jul;70(7):685-7. Doi: https://doi.org/10.1055/s-2004-827196. 
9. Gilchrist T. Aromatic heterocycles. In: Heterocyclic chemistry. Harlow, UK: Longman Scientific \& Technical; 1985. p. 5-19.

10. Hattori M, Hada S, Watahiki A, Ihara H, Shu Y$Z$, Kakiuchi $N$, et al. Studies on dental caries prevention by traditional medicines. $X$ Antibacterial action of phenolic components from mace against Streptococcus mutans. Chem Pharm Bull. 1986;34(9):3885-93. https://doi.org/10.1248/cpb.34.3885.

11. Erber S, Ringshandl R, von Angerer E. 2Phenylbenzo[b]furans: relationship between structure, estrogen receptor affinity and cytostatic activity against mammary tumor cells. Anticancer Drug Des. 1991 Nov;6(5):417-26. Url: https://pubmed.ncbi.nlm.nih.gov/1764164/.

12. Cui B, Chai $H$, Santisuk T, Reutrakul V, Farnsworth NR, Cordell GA, et al. Novel cytotoxic $1 \mathrm{H}$-cyclopenta[b]benzofuran lignans from Aglaia elliptica. Tetrahedron. 1997 Dec;53(52):17625-32. Doi: 4020(97)10231-9.

13. Lee SK, Cui B, Mehta RR, Kinghorn AD, Pezzuto JM. Cytostatic mechanism and antitumor potential of novel $1 \mathrm{H}$-cyclopenta[b]benzofuran lignans isolated from Aglaiaelliptica. Chemico-Biological Interactions. 1998 Oct;115(3):215-28. Doi: https://doi.org/10.1016/S0009-2797(98)00073-8.

14. Kodama I, Kamiya K, Toyama J. Amiodarone: ionic and cellular mechanisms of action of the most promising class III agent. The American Journal of Cardiology. 1999 Nov;84(9):20-8. Doi: https://doi.org/10.1016/S0002-9149(99)00698-0.

15. Hayakawa I, Shioya R, Agatsuma T, Furukawa $H$, Naruto S, Sugano Y. 4-Hydroxy-3-methyl-6phenylbenzofuran-2-carboxylic acid ethyl ester derivatives as potent anti-tumor agents. Bioorganic \& Medicinal Chemistry Letters. 2004 Jan;14(2):4558.

Doi:

https://doi.org/10.1016/j.bmcl.2003.10.039.

16. Hwang BY, Su B-N, Chai H, Mi Q, Kardono LBS, Afriastini JJ, et al. Silvestrol and Episilvestrol, Potential Anticancer Rocaglate Derivatives from Aglaia silvestris. J Org Chem. 2004 Sep;69(18):6156-6156. https://doi.org/10.1021/jo040008h.

17. Masche UP, Rentsch KM, von Felten A, Meier PJ, Fattinger KE. No clinically relevant effect of Iornoxicam intake on acenocoumarol pharmacokinetics and pharmacodynamics. European Journal of Clinical Pharmacology. 1999 Jan 20;54(11):865-8. Doi:
18. Karaliota A, Kretsi O, Tzougraki C. Synthesis and characterization of a binuclear coumarin-3carboxylate copper(II) complex. Journal of Inorganic Biochemistry. 2001 Mar;84(1-2):33-7. Doi: https://doi.org/10.1016/S0162-0134(00)00214-2.

19. Kossakowski J, Krawiecka M, Kuran B, Stefańska J, Wolska I. Synthesis and Preliminary Evaluation of the Antimicrobial Activity of Selected 3Benzofurancarboxylic Acid Derivatives. Molecules. 2010 Jul 6;15(7):4737-49. Doi: https://doi.org/10.3390/molecules15074737.

20. Tsuji H, Mitsui C, Ilies L, Sato $Y$, Nakamura E. Synthesis and Properties of 2,3,6,7Tetraarylbenzo[1,2- b:4,5- b ']difurans as HoleTransporting Material. J Am Chem Soc. 2007 Oct $1 ; 129(39): 11902-3$. https://doi.org/10.1021/ja074365w.

21. Anderson S, Taylor PN, Verschoor GLB. Benzofuran Trimers for Organic Electroluminescence. Chem Eur J. 2004 Jan 23;10(2):518-27. Doi: https://doi.org/10.1002/chem.200305284.

22. Creaven BS, Devereux M, Georgieva I, Karcz D, McCann M, Trendafilova N, et al. Molecular structure and spectroscopic studies on novel complexes of coumarin-3-carboxylic acid with $\mathrm{Ni}(\mathrm{II}), \mathrm{Co}(\mathrm{II})$, $\mathrm{Zn}$ (II) and $\mathrm{Mn}$ (II) ions based on density functional theory. Spectrochimica Acta Part A: Molecular and Biomolecular Spectroscopy. 2011 Dec;84(1):27585. Doi: https://doi.org/10.1016/j.saa.2011.09.041.

23. Castellani CB, Carugo O. Studies on fluorescent lanthanide complexes. New complexes of lanthanides(III) with coumarinic-3-carboxylic acid. Inorganica Chimica Acta. 1989 May;159(2):157-61. Doi: 1693(00)80560-5.

24. Georgieva I, Trendafilova N, Aquino AJA, Lischka $\mathrm{H}$. Theoretical Study of Metal-Ligand Interaction in Sm(III), Eu(III), and Tb(III) Complexes of Coumarin-3-Carboxylic Acid in the Gas Phase and Solution. Inorg Chem. 2007 Dec 1;46(25):1092636. Doi: https://doi.org/10.1021/ic7016616.

25. Georgieva I, Trendafilova N, Creaven BS, Walsh $M$, Noble A, McCann M. Is the CO frequency shift a reliable indicator of coumarin binding to metal ions through the carbonyl oxygen? Chemical Physics. 2009 Nov;365(1-2):69-79. Doi: https://doi.org/10.1016/j.chemphys.2009.10.004.

26. Mihaylov Tz, Trendafilova N, Kostova I, Georgieva I, Bauer G. DFT modeling and spectroscopic study of metal-ligand bonding in $\mathrm{La}$ (III) complex of coumarin-3-carboxylic acid. 
Chemical Physics. 2006 Sep;327(2-3):209-19. Doi: https://doi.org/10.1016/j.chemphys.2006.04.009.

27. Roh, Soo-Gyun, Baek, Nam Seob, Hong, KyongSoo, 김환규. Synthesis and Photophysical Properties of Luminescent Lanthanide Complexes Based on Coumarin-3-carboxylic Acid for Advanced Photonic Applications. Bulletin of the Korean Chemical Society. 2004 Mar 20;25(3):343-4. Doi: https://doi.org/10.5012/BKCS.2004.25.3.343.

28. Köse DA, Öztürk B, Şahin $O$, Büyükgüngör $O$. Mixed ligand complexes of coumarilic acid/nicotinamide with transition metal complexes: Synthesis and structural investigation. J Therm Anal Calorim. 2014 Feb;115(2):1515-24. Doi: https://doi.org/10.1007/s10973-013-3415-6.

29. Ng SW. Coordination complexes of triphenyltin coumarin-3-carboxylate with $\mathrm{O}$-donor ligands: (coumarin-3-carboxylato)triphenyltin- $\mathrm{L}(\mathrm{L}=$ ethanol, diphenylcyclopropenone and quinoline $\mathrm{N}$ oxide) and bis[(coumarin-3carboxylato)triphenyltin]- $\mathrm{L} \quad(\mathrm{L}=$ triphenylphosphine oxide and triphenylarsine oxide). Acta Crystallogr C Cryst Struct Commun. 1999 Apr $15 ; 55(4): 523-31$.

https://doi.org/10.1107/S0108270198014991.

30. Ng SW, Kumar Das VG. Tetramethylammonium Bis(coumarin-3-carboxylato)triphenylstannate

Ethanol Solvate. Acta Crystallogr C Cryst Struct Commun. 1997 Aug 15;53(8):1034-6. Doi: https://doi.org/10.1107/S0108270197004307.

31. Mosa AI, Emara AAA, Yousef JM, Saddiq AA. Novel transition metal complexes of 4-hydroxycoumarin-3-thiocarbohydrazone: Pharmacodynamic of $\mathrm{Co}$ (III) on rats and antimicrobial activity. Spectrochimica Acta Part A: Molecular and Biomolecular Spectroscopy. 2011 Oct;81(1):35-43. Doi: https://doi.org/10.1016/j.saa.2011.05.035.

32. Weder JE, Dillon CT, Hambley TW, Kennedy BJ, Lay PA, Biffin JR, et al. Copper complexes of nonsteroidal anti-inflammatory drugs: an opportunity yet to be realized. Coordination Chemistry Reviews. 2002 Oct;232(1-2):95-126. Doi: https://doi.org/10.1016/S0010-8545(02)00086-3.

33. Tisato F, Marzano C, Porchia M, Pellei M, Santini C. Copper in diseases and treatments, and copperbased anticancer strategies. Med Res Rev. 2009;30(4): 708-49.

https://doi.org/10.1002/med.20174.

34. Bareggi SR, Cornelli U. Clioquinol: Review of its Mechanisms of Action and Clinical Uses in Neurodegenerative Disorders: Clioquinol. CNS Neuroscience \& Therapeutics. 2012 Jan;18(1):41-6. Doi: https://doi.org/10.1111/j.1755-
35. Duncan C, White AR. Copper complexes as therapeutic agents. Metallomics. 2012;4(2):127-38. Doi: https://doi.org/10.1039/C2MT00174H.

36. a) Drzewiecka A, Koziol AE, Klepka MT, Wolska A, Jimenez-Pulido SB, Lis $T$, et al. Two coordination modes around the $\mathrm{Cu}$ (II) cations in complexes with benzo[b]furancarboxylic acids. Chemical Physics Letters. 2013 Feb;559:41-5. Doi: https://doi.org/10.1016/j.cplett.2013.01.011. .b) Drzewiecka A, Koziol AE, Klepka MT, Wolska A, Jimenez-Pulido SB, Struga $M$. Electrochemical synthesis and structural studies of zinc(II) complexes with derivatives of benzo[b]furancarboxylic acids. Chemical Physics Letters. 2013 Jun;575:40-5. Doi: https://doi.org/10.1016/j.cplett.2013.04.078.

37. Dağlı Ö, Köse DA, Şahin O, Şahin ZS. The synthesis and structural characterization of transition metal coordination complexes of coumarilic acid. J Therm Anal Calorim. 2017 Jun; 128(3):1373-83.

Doi.

https://doi.org/10.1007/s10973-016-6053-y.

38. Dağlı Ö, Köse DA, İçten $O, A v c ı$ GA, Şahin O. The mixed ligand complexes of $\mathrm{Co}(\mathrm{II}), \mathrm{Ni}(\mathrm{II}), \mathrm{Cu}(\mathrm{II})$ and $\mathrm{Zn}$ (II) with coumarilic acid/1,10phenanthroline: Synthesis, crystal characterization and biological applications. J Therm Anal Calorim. 2019 May;136(4):1467-80. Doi: https://doi.org/10.1007/s10973-018-7773-y.

39. Koç S, Köse DA, Avcı E. Synthesis, Structural Characterization and Biological Application of Mixed Ligands Complexes of Coumaric Acid/Coumarine with Some Transition Metal Cation. European Chemical Bulletin. 2016;5(4):132-7.

40. Koc S, Kose DA, Avci E. Synthesis and Thermal Characterization of $p$-Coumaric Acid Complexes of CoII, NiII, CuII and ZnII Metal Cations and Biological Applications. Hittite J Sci Eng. 2016;3(1):15-22.

https://doi.org/10.17350/HJSE19030000027.

41. Dağlı Ö, Köse DA, Avcı GA, Şahin O. Novel mixed-ligand complexes of coumarilate/N, $N^{\prime}-$ diethylnicotinamide with some transition metals: Synthesis and structural characterization. J Therm Anal Calorim. 2017 Sep;129(3):1389-402. Doi: https://doi.org/10.1007/s10973-017-6373-6.

42. Srinivasan BR, Shetgaonkar SY, Näther C, Bensch W. Solid state synthesis and characterization of a triple chain calcium(II) coordination polymer showing two different bridging 4-nitrobenzoate coordination modes. Polyhedron. 2009 Feb;28(3):534-40. Doi: 
43. Elin RJ. Assessment of magnesium status. Clinical Chemistry. 1987 Nov 1;33(11):1965-70. Doi: https://doi.org/10.1093/clinchem/33.11.1965.

44. Purvis JR, Movahed A. Magnesium disorders and cardiovascular diseases. Clin Cardiol. 1992 Aug;15(8):556-68.

https://doi.org/10.1002/clc.4960150804.

45. Rabbani LE, Antman EM. The role of magnesium therapy in acute myocardial infarction. Clin Cardiol. 1996 Nov; 19(11):841-4.

Doi: https://doi.org/10.1002/clc.4960191103.

46. Ralston MA, Murnane MR, Kelley RE, Altschuld RA, Unverferth DV, Leier CV. Magnesium content of serum, circulating mononuclear cells, skeletal muscle, and myocardium in congestive heart failure. Circulation. 1989 Sep;80(3):573-80. Doi: https://doi.org/10.1161/01.CIR.80.3.573.

47. Lim $P$, Jacob E. Magnesium Deficiency in Patients on Long-Term Diuretic Therapy for Heart Failure. BMJ. 1972 Sep 9;3(5827):620-2. Doi: https://doi.org/10.1136/bmj.3.5827.620.

48. Radecka-Paryzek W, Patroniak V. The template synthesis and characterization of alkaline earth metal ion nitrate macroacyclic Schiff base complexes. Polyhedron. 1994 Jul;13(14):2125-8. Doi: https://doi.org/10.1016/S0277-
49. Bock CW, Katz AK, Glusker JP. Hydration of Zinc Ions: A Comparison with Magnesium and Beryllium Ions. J Am Chem Soc. 1995 Apr;117(13):3754-65. Doi. https://doi.org/10.1021/ja00118a012.

50. Katz AK, Glusker JP, Beebe SA, Bock CW. Calcium Ion Coordination: A Comparison with That of Beryllium, Magnesium, and Zinc. J Am Chem Soc. 1996 Jan;118(24):5752-63. Doi: https://doi.org/10.1021/ja953943i.

51. Carugo O, Djinovi? K, Rizzi M. Comparison of the co-ordinative behaviour of calcium(II) and magnesium(II) from crystallographic data. J Chem Soc, Dalton Trans. 1993;(14):2127. Doi: https://doi.org/10.1039/dt9930002127.

52. Peschke $M$, Blades AT, Kebarle $P$. Hydration Energies and Entropies for $\mathrm{Mg} \mathrm{2+}, \mathrm{Ca} \mathrm{2+}, \mathrm{Sr} 2+$, and $\mathrm{Ba} 2+$ from Gas-Phase Ion-Water Molecule Equilibria Determinations. J Phys Chem A. 1998 Nov $1 ; 102(48): 9978-85$. https://doi.org/10.1021/jp9821127.

53. Refat MS, Alghool S, El-Halim HFA. Alkaline earth metal (II) complexes of vitamin B13 with bidentate orotate ligands: Synthesis, structural and thermal studies. Comptes Rendus Chimie. 2011 May; 14(5):496-502.

Doi:

https://doi.org/10.1016/j.crci.2010.04.024. 